ANNA NIERZEWSKA iD orcid.org/0000-0002-9892-3211

Katedra Psychologii, Uniwersytet Pedagogiczny im. KEN w Krakowie Chair of Psychology, Pedagogical University of Cracow e-mail: anna.nierzewska@up.krakow.pl

EWA GURBA iD orcid.org/0000-0003-3838-6570

Instytut Psychologii, Uniwersytet Jagielloński, Kraków Institute of Psychology, Jagiellonian University in Kraków e-mail: ewa.gurba@uj.edu.pl.

\title{
Wybrane uwarunkowania postaw osób u progu dorosłości wobec starości i seniorów
}

\section{Selected Determinants of Attitudes of Emerging Adults towards Old Age and Seniors}

\begin{abstract}
The number of elderly people in the population is constantly increasing. The seniors' wellbeing relies heavily not only upon the activities they undertake but also on the attitude of the society toward them. Of particular importance is the attitude of the emerging adults, because it is at this stage that the process of the identity formation takes place. The aim of the study was to discover the state of knowledge, attitudes, and the frequency and quality of contacts with elderly people among the emerging adults. 180 students ( 87 women and 93 men) aged $18-25(M=22.5)$ participated in the study. The following tools were applied: the author's own questionnaire to measure the contact frequency and quality, the Kogan's Attitudes Towards Old People, and the Palmore's Facts on Aging Quiz. Emerging adults have proven to hold ambivalent attitudes toward old people. A significant correlation has been found between the knowledge and the attitudes. The frequency of contact with elderly people was negatively correlated with the intensity of the negative attitude. The quality of contact with elderly people differentiates the emerging adults' attitudes.
\end{abstract}

Keywords: elderly people, emerging adulthood, attitudes towards elderly people, ageism, gerontophobia.

Słowa kluczowe: osoby starsze, wkraczanie w dorosłość, postawy wobec osób starszych, ageizm, gerontofobia.

\section{WPROWADZENIE}

Świat mierzy się dziś z wyzwaniem podwójnego starzenia się społeczeństw, nie tylko wzrasta bowiem liczba osób powyżej sześćdziesiątego roku życia w społeczeństwie, lecz także rośnie odsetek tych, które przekroczyły osiemdziesiąty rok życia. Mówi się też o zjawisku siwiejącej populacji. To wzrost liczby osób, które sąjeszcze aktywne w przestrzeni społecznej, ale przekroczyły próg późnej dorosłości. Światowa Organizacja Zdrowia (National Institute on Aging and World Health Organization, 2011) podaje, że z problemem starzejącego się społeczeństwa borykają się już kraje wysoko rozwinięte. Z danych Eurostatu (Social Europe, 2011) wynika, 
że ludność powyżej sześćdziesiątego roku życia stanowi 24\% populacji Unii Europejskiej, a w Polsce odsetek osób starszych sięga 20\%. Na 2050 rok prognozowany jest już trzykrotny wzrost liczby ludności po sześćdziesiątym piatym roku życia (World Population Aging, 2015). Powyższe dane mają odzwierciedlenie w zwiększającym się udziale osób starszych w przestrzeni społecznej. Niezmiernie ważne jest zatem kształtowanie wobec tej grupy właściwych postaw młodych ludzi. To dzisiejsi młodzi w przyszłości wyznaczać będą jakość polityki społecznej wobec osób w zaawansowanym wieku.

Nie da się ukryć, że wraz z upływem lat człowiek dorosły staje wobec coraz trudniejszych wyzwań. Spotykane w codziennym życiu utrudnienia związane z wiekiem przekładają się na poczucie dobrostanu osób starszych. Badania Molzahn, Skevington, Kalfoss i Makaroff (2010) pokazują, że do czynników decydujących o jakości życia należą: zdolność do wykonywania czynności życia codziennego, stan zdrowia, sprawność sensoryczna, sprawność motoryczna, niezależność, energia, życie seksualne, zdolność do nabywania nowych umiejętności, aktywne uczestnictwo w życiu społecznym, obraz ciała oraz nastawienie do śmierci. Znaczenie poszczególnych czynników różni się w zależności od fazy okresu senioralnego. We wczesnej starości (60-74), $\mathrm{W}$ porównaniu $\mathrm{z}$ późna $(75+)$, bardziej istotne okazują się: pozytywny obraz siebie, zdolność do nabywania nowych umiejętności i aktywne życie seksualne (Kalfoss, Halvorsrud, 2009). Znaczenie ma także płeć, bo choć wszyscy seniorzy najwyżej cenią umiejętność wykonywania codziennych czynności, możliwość samodzielnego poruszania się oraz dobry stan zdrowia, to dla kobiet dodatkowo ważna jest jakość relacji społecznych, pozytywny obraz ciała oraz sprawność poznawcza i sensoryczna, a dla mężczyzn nieodczuwanie bólu oraz życie seksualne. W ogólnopolskich badaniach z udziałem ponad trzech tysięcy seniorów więcej niż połowa określiła jakość swojego życia jako dobrą lub bardzo dobrą (Waszkiewicz i in., 2012). Mężczyźni w porównaniu z kobietami byli bardziej zadowoleni z ogólnej jakości ży- cia, jak i ze stanu zdrowia, a mniej z własnych relacji społecznych. Jak wynika z badań, pozytywna percepcja starości, która może wynikać również z postaw pozostałych członków społeczeństwa wobec seniorów, sprzyja ich dobrej kondycji fizycznej (Levy, Slade, Kunkel, Kasl, 2002).

\section{AGEIZM I GERONTOFOBIA - ZJAWISKA SPECYFICZNE DLA WSPÓŁCZESNEGO SPOŁECZEŃSTWA}

Wejście w okres późnej dorosłości to nie tylko czas pojawiania się zauważalnych oznak biologicznego starzenia się, lecz także przejścia do społecznie nowej grupy - seniorów i emerytów. Mimo że dorosłość przypada na okres od dwudziestego-dwudziestego drugiego roku życia do śmierci, to osoby po sześćdziesiątym piątym roku życia częściej określane są jako seniorzy niż dorośli. To zróżnicowanie wiąże się z odmiennym, w porównaniu z ogółem dorosłych, spostrzeganiem osób starszych i nastawieniem wobec nich. Cechy przypisywane osobom w późnej dorosłości z reguły związane są z nieprawdziwymi i negatywnymi stereotypami (Denmark, 2002), co sprzyja dyskryminowaniu tych osób z uwagi na wiek (zjawisko ageizmu - por. Butler, 1980) i w konsekwencji z jednej strony prowadzi do marginalizacji seniorów przez społeczeństwo, a z drugiej do wycofywania się przez nich samych z aktywności społecznej. Ageizm stanowi, obok rasizmu i seksizmu, najczęstszą formę dyskryminacji. Jego przejawy są subtelne i prawdopodobnie z tego powodu wciąż akceptowane społecznie. Ponad połowa Polaków uważa na przykład, że jest to zjawisko rozpowszechnione, a nawet jedna trzecia ankietowanych była świadkiem dyskryminacji ze względu na wiek (Special Eurobarometer, 2009).

Ageizm budowany jest na stereotypowym postrzeganiu osób starszych jako zniedołężniałych, słabych i schorowanych, a także poprzez uznawanie starości za bezwartościowy czas ciagłych strat i zaniku sił witalnych. Przejawem ageizmu jest społeczna dyskryminacja osób starszych w miejscu pracy, w dostępie do edukacji 
lub do opieki medycznej. W najbardziej nasilonej postaci wiąże się z lekceważeniem potrzeb seniorów, a nawet aktami przemocy wobec nich (Bousfield i Hutchison, 2010). Istotnym źródłem dyskryminacji seniorów jest gerontofobia, czyli lęk osób młodszych przed własną starością i śmiercią oraz jego transmisja na osoby starsze (Trempała, Zając-Lamparska, 2007). Zarówno gerontofobia, jak i zaprzeczanie procesom własnego starzenia się moga podsycać w jednostce skłonności do ageizmu, co na zasadzie mechanizmu sprzężenia zwrotnego nasila lęk wobec starości.

Innymi przyczynami dyskryminacji z uwagi na wiek mogą być: brak wiedzy na temat starzenia się i starości, bezrobocie nasilające konkurencję na rynku pracy oraz niedostateczne przystosowanie instytucji państwowych do potrzeb seniorów (Szatur-Jaworska, 2010). Uboga wiedza na temat starzenia się i starości, akty ageizmu oraz gerontofobia obecne w życiu społecznym mogą skutkować nasilaniem się negatywnej postawy osób młodszych w stosunku do seniorów. Postawę rozumiemy tutaj jako względnie trwałą tendencję do wartościowania jakiegoś przedmiotu, zdarzenia, osoby lub grupy osób. Może ona mieć charakter pozytywny lub negatywny i przejawiać się poprzez wzbudzenie konkretnych emocji czy automatycznych reakcji na pojawienie się danego bodźca lub nawet na samą myśl o nim (Wojciszke, 2011). Im ważniejsza jest dana postawa dla jednostki, tym trudniej ją zmienić. W związku z nasilającym się zjawiskiem podwójnego starzenia się, czyli jednoczesnego wzrostu w populacji odsetka osób po sześćdziesiątym i po osiemdziesiątym roku życia, kreowanie odpowiednich postaw wobec osób starszych, staje się ważnym komponentem dobrego funkcjonowania zarówno seniorów, jak i ogółu społeczeństwa (Ostril, Ottenbacher, Markides, 2004). Dotychczasowe badania dotyczące postaw wobec seniorów wśród różnych grup społecznych nie dostarczają spójnych wyników. Możliwe, że negatywne myślenie o starości i starzeniu się powoli słabnie (Trempała, Zając-Lamparska, 2007; Zając-Lamparska, 2008a), a w jego miejsce pojawia się obojętność wobec osób starszych (Miłkowska, 2014).

\section{SENIORZY W OCZACH MLODYCH LUDZI WKRACZAJĄCYCH W DOROSŁOŚĆ}

Z punktu widzenia społecznego funkcjonowania seniorów szczególnie ważne są postawy przejawiane wobec nich przez osoby wkraczające w dorosłość i młodych dorosłych. Te osoby w niedługiej przyszłości będą bowiem zarządzać instytucjami społecznymi i decydować o warunkach życia osób w starszym wieku.

Okres wyłaniającej się dorosłości to czas zawieszenia między adolescencją a dorosłością, w którym młodzi ludzie coraz wyraźniej określają własną tożsamość poprzez preferencje w systemie wartości, celach i światopoglądzie ujawniające się w aktywności zawodowej oraz relacjach interpersonalnych. Wiara w możliwość realizacji własnych marzeń oraz poczucie, że w każdej chwili można spróbować czegoś innego i na żadną decyzję nie jest za późno, najsilniej ujawnia się właśnie w tym okresie życia (Arnett, 2004, 2006). Koncentracja na sobie i poczucie nieograniczonych możliwości, charakterystyczne dla osób w tej fazie rozwoju, mogą rzutować na przejawiane przez nich postawy wobec osób starszych. Z jednej strony swoisty egocentryzm młodych wkraczających w dorosłość sprzyja odkrywaniu własnego potencjału i w konsekwencji ułatwia formułowanie ambitnych planów i celów życiowych. Z drugiej zaś może utrudniać zrozumienie aktywności, a przede wszystkim ograniczeń osób reprezentujących wiekowo odległe pokolenie, dla którego charakterystyczne jest raczej doświadczanie ograniczeń niż możliwości. Więzi młodych $\mathrm{z}$ rówieśnikami, tworzone i umacniane we wspólnie podzielanych, różnych formach działania (młodzi w tej fazie rozwoju odraczający zakładanie własnej rodziny intensywnie angażują się w relacje ze znajomymi i przyjaciółmi) skutkują silną identyfikacją z własnym pokoleniem: ludzi o najlepszej w biegu życia kondycji fizycznej i psychicznej (Gurba, 2011), pogłębiając przepaść między młodością a starością. Doświadczenia związane z zaspokajaniem potrzeby autonomii, szczególnie cenione i będące udziałem osób w wyłaniającej się dorosłości mogą powodować krytyczne spojrze- 
nie na ludzi, których autonomia ograniczana jest przez obniżającą się sprawność fizyczną, a także przez trudne do przekroczenia bariery społeczne.

Wymienione cechy młodych ludzi będących u progu dorosłości mogą zatem stanowić jedno ze źródeł ich postaw wobec seniorów. Liczne badania zdają się potwierdzać te przypuszczenia, bowiem jak stwierdziła Miłkowska (2014), postawy młodych dorosłych nacechowane są obojętnością i zdystansowaniem wobec osób starszych. Zwraca się też uwagę na doświadczanie przez młodych lęku przed własną starością i związanego z nim lęku przed przebywaniem w towarzystwie osób starszych jako przyczyny nieprzychylnego do nich odnoszenia się (Schwartz, Simmons, 2001). Udział niskiego poziomu lęku młodych przed kontaktami z seniorami w kształtowaniu ich pozytywnego stosunku do osób starszych odnotowano natomiast w badaniach studentów londyńskich. W grupie tej zaobserwowano też związek między postrzeganą przez młodych ludzi jakością kontaktu z seniorami a ich postawami wobec tej grupy. Nie dostrzeżono natomiast znaczenia częstości kontaktów studentów z osobami starszymi dla ustosunkowania się młodych wobec seniorów (Bousfield, Hutchison, 2010).

Poziom wiedzy młodych dorosłych o starości i starzeniu się stanowi kolejny istotny warunek decydujący o sposobie ich odnoszenia się do osób starszych. Z badań wynika, że większość studentów ujawnia różne formy ageizmu i negatywne postawy wobec osób starszych, przy jednoczesnym niskim poziomie wiedzy o starości i starzeniu się (Lee, 2009; Lucacel, Baban, 2014). W porównaniu z tymi wynikami odmiennie prezentują się postawy młodych Polaków wobec seniorów. Rezultaty badań Trempały i Zając-Lamparskiej (2007) wskazują bowiem, że Polacy wkraczający w dorosłość cechują się pozytywną postawą wobec osób starszych, choć kontakt z nimi oceniają negatywnie. Pozytywnej postawie sprzyja osobisty kontakt z konkretnymi osobami starszymi (Zając-Lamparska, 2008a), natomiast kiedy seniorzy traktowani są przez młodych jako grupa wiekowa, to pozytywna postawa ujawnia się jedynie w odpowiedziach kobiet.
Wynikać to może z faktu, że kobiety w porównaniu z mężczyznami są bardziej pozytywnie nastawione do ludzi w każdym wieku. Z kolei wyniki badań Miłkowskiej (2014) wskazują na ambiwalencję w postawach studentów względem osób starszych, przy czym postawy negatywne przybierały raczej postać dystansu aniżeli wrogości wobec nich. Autorka postuluje, iż taka postawa może być tłumaczona niewielką wiedzą na temat starości, a także brakiem kontaktu z osobami starszymi. Ponadto zdystansowana postawa chroni młodego człowieka przed zmierzeniem się z lękiem wobec własnej starości. Jak widać, wyniki prezentowanych badań najczęściej przedstawiają postawy osób wkraczających w dorosłość wobec seniorów jako ambiwalentne oraz zdystansowane, a pozytywny stosunek do seniorów wiązany jest z posiadaniem adekwatnej wiedzy dotyczącej starości i zależy od niskiego poziomu lęku wobec własnej starości oraz większej częstości przebywania w towarzystwie osób starszych.

\section{PROBLEM BADAWCZY}

W opisanej poniżej eksploracji podjęto próbę określenia znaczenia kilku wybranych uwarunkowań postaw osób wkraczających w dorosłość wobec seniorów, takich jak wiedza o seniorach oraz częstość i jakość kontaktów $\mathrm{z}$ nimi. W prezentowanym badaniu zmiennymi wyjaśnianymi są zatem nasilenie pozytywnej i negatywnej postawy młodych ludzi wobec seniorów (wskaźniki: wyniki w skalach postawy pozytywnej i negatywnej w Kwestionariusz postaw wobec osób starszych Kogana), a zmiennymi wyjaśniającymi wiedza studentów o seniorach (wskaźnik: wynik w Kwestionariuszu wiedzy o starzeniu się Palmore'a) oraz częstość i jakość kontaktów z nimi (wskaźniki: wyniki w Ankiecie kontaktu z osobami starszymi).

Celem przeprowadzonego badania było zweryfikowanie następujących hipotez:

1. Istnieje pozytywny związek między poziomem wiedzy na temat starości i starzenia się osób wkraczających w dorosłość a ich postawą wobec osób w wieku senioralnym. 
2. Częstość kontaktu osób wkraczających w dorosłość z seniorami powiązana jest $\mathrm{z}$ ich postawami wobec seniorów. Im częściej młodzi ludzie kontaktują się z seniorami, tym bardziej nasilona jest ich pozytywna postawa, a mniej nasilona negatywna wobec osób starszych.

3. Istnieje związek między jakością kontaktów osób wkraczających w dorosłość z seniorami a ich postawami wobec seniorów. Badani relacjonujący pozytywny kontakt z seniorami w porównaniu z rówieśnikami o gorszym kontakcie ujawniają bardziej pozytywną postawę wobec osób starszych, a mniej nasiloną postawę negatywną.

4. Wiedza badanych studentów na temat seniorów i procesu starzenia się stanowi najważniejszy predyktor spośród rozważanych uwarunkowań ich postawy wobec osób starszych.

\section{METODA}

\section{Osoby badane}

W celu sprawdzenia hipotez badawczych zaprojektowano badania kwestionariuszowe.

W badaniach wzięło udział 180 osób (87 kobiet i 93 mężczyzn) w wieku 18-25 lat. Średnia wieku badanych wynosiła 22,5 roku. Badanymi byli studenci krakowskich uczelni wyższych Uniwersytetu Jagiellońskiego oraz Akademii Górniczo-Hutniczej. Osoby badane tworzyły grupę zróżnicowaną pod względem kierunku studiów (biologia, historia, religioznawstwo, muzykologia, matematyka oraz mechanika i budowa maszyn). Badania przeprowadzano grupowo w trakcie zajęć po wcześniejszym uzyskaniu zgody studentów oraz prowadzących zajęcia.

\section{Narzędzia badawcze}

Do badania wykorzystano trzy narzędzia: Ankietę kontaktu z osobami starszymi, Kwestionariusz wiedzy o starzeniu się Palmore'a (Palmore's Facts on Aging Quiz) oraz Kwestionariusz postaw wobec osób starszych Kogana (The
Kogan's Attitudes Toward Old People Scale). Poniżej przedstawiono szczegółowy opis każdego z nich.

1. Ankieta kontaktu z osobami starszymi to narzędzie własnego autorstwa. Składa się z dwunastu pytań o doświadczenia kontaktu badanego z osobami starszymi. Pięć pytań sprawdza częstość kontaktu zarówno aktualnego, jak i w przeszłości. Cztery pytania dotyczą emocji i zachowań, z których można wnioskować o jakości tego kontaktu. Dodatkowo załączono trzy pytania umożliwiające zorientowanie się w charakterze kontaktów studentów z seniorami: 1. Czy utrzymuje Pan/Pani kontakt z osobami starszymi, które nie należą do rodziny? 2. Jak ważne są dla Pana/Pani kontakty z osobami starszymi? oraz 3. Czy mieszka lub mieszkał/a Pan/Pani kiedykolwiek z osobami starszymi? Dane otrzymane z zastosowania ankiety posłużyły do oceny częstości kontaktów studentów z osobami starszymi oraz postrzeganej przez nich jakości kontaktu.

2. Kwestionariusz wiedzy o starzeniu się autorstwa Erdmana Palmore'a (Palmore's Facts on Aging Quiz) składa się z 25 stwierdzeń dotyczących fizycznych, psychicznych i społecznych aspektów starości i starzenia się. Zadaniem osoby badanej jest określenie, czy podane stwierdzenie jest prawdziwe, czy fałszywe. Za każdą poprawną odpowiedź uzyskuje się jeden punkt. Im więcej punktów, tym wyższy poziom wiedzy o starości i starzeniu się. Prawdziwe i fałszywe stwierdzenia występują w kwestionariuszu naprzemiennie. Jak podaje sam autor, nikt $\mathrm{z}$ badanych nie odkrył tej reguły (Palmore, 1977). Zdecydowano się na użycie Kwestionariusza wiedzy o starzeniu się Palmore'a ze względu na jego szerokie wykorzystanie w badaniach prowadzonych na grupach różnych narodowości oraz możliwość porównania wyników z badań własnych z innymi opisywanymi w literaturze przedmiotu (Lee, 2009; Pennington, Pachana, Coyle, 2001; Romeis, Sussmann, 1982). Narzędzie nie posiada polskiej adaptacji, dlatego na potrzeby pracy dokonano jego tłumaczenia. W stwierdzeniach numer 19 („,Ponad 25\% 
populacji polskiej ma powyżej 65 lat”) i 25 (,W 2050 roku poziom zdrowia i sytuacja materialna osób starszych w stosunku do młodszych będzie taka sama jak obecnie") wprowadzono modyfikacje w zakresie procentu populacji i roku, aby odpowiedź na pytania pozostała taka sama, jak w oryginalnej wersji. (W przypadku obu pytań prawidłową odpowiedzią jest ,fałsz”).

3. Kwestionariusz postaw wobec osób starszych to narzędzie autorstwa Nathana Kogana (The Kogan's Attitudes Toward Old People Scale, 1961). Składa się z 17 par stwierdzeń pozytywnych i negatywnych dotyczących osób starszych. Osoba badana zaznacza na pięciostopniowej skali (nie zgadzam - raczej się nie zgadzam - nie mam zdania - raczej się zgadzam - zgadzam się), w jakim stopniu zgadza się z każdym stwierdzeniem. Poszczególne pary itemów dotyczą miejsca zamieszkania seniorów, odczuwania dyskomfortu, który może się pojawiać $\mathrm{w}$ ich towarzystwie, relacji międzygeneracyjnych, możliwości poznawczych osób starszych, ich wyglądu osobistego i osobowości. Kwestionariusz składa się z dwóch podskal: podskali postawy pozytywnej i podskali postawy negatywnej. W każdej można uzyskać wynik od 17 do 85 punktów. Wyższy wynik w każdej z podskal oznacza większe nasilenie postawy pozytywnej/negatywnej. W badaniach własnych zatytułowano ten kwestionariusz Osoby starsze w społeczeństwie, aby uniknąć podawania wprost celu pomiaru, jakim jest określenie postawy wobec osób starszych.

\section{Procedura badania}

Badania przeprowadzono od marca do maja 2017 roku. Miały one charakter zbiorowy. Studenci byli proszeni o wypełnienie trzech kwestionariuszy na temat osób starszych i wypełniali je w następującej kolejności: Ankieta kontaktu z osobami starszymi, Kwestionariusz wiedzy o starzeniu się i Kwestionariusz postaw wobec osób starszych Kogana. Instrukcje do kwestionariuszy zawierały dodatkowo definicję osoby starszej jako tej, która ukończyła sześćdziesiąty piąty rok życia. Na końcu badania podawano studentom bardziej szczegółowe wyjaśnienie jego celu.

\section{WYNIKI}

Przed przystapieniem do testowania hipotez sprawdzono rzetelność technik przetłumaczonych na potrzeby niniejszej pracy Kwestionariusza wiedzy o starzeniu się Palmore'a oraz Kwestionariusza postaw wobec osób starszych Kogana. Oryginalna wersja kwestionariusza Palmore'a cechuje się rzetelnością na poziomie $\alpha=.40$. Rzetelność polskiej wersji kwestionariusza wynosi $\alpha=.36$. Niski współczynnik homogeniczności wynika z faktu, iż choć kwestionariusz służy do badania jednego konstruktu - wiedzy o starości, to pytania odnoszą się do różnych jej aspektów (fizycznych, psychicznych i społecznych). Podskale kwestionariusza w polskim thumaczeniu charakteryzują się rzetelnością: dla podskali postawy pozytywnej $\alpha=$ $.70 \mathrm{i}$ dla podskali postawy negatywnej $\alpha=.78$. Ze względu na otrzymane rzetelności zdecydowano się na wyodrębnienie tych dwóch podskal w dalszej analizie. Za ich wyodrębnieniem przemawiała także istotna ujemna korelacja między skalami $(r=-.60 ; p<.01)$.

\section{Nasilenie pozytywnych i negatywnych postaw studentów wobec seniorów}

Średnie wyniki nasilenia postaw studentów wobec osób starszych na podskali postawy pozytywnej wynosza: $M=51.8, S D=6.9$, a na podskali postawy negatywnej: $M=45.6, S D=$ 8.4. Różnica między średnimi wynikami w obu podskalach była istotna statystycznie ( $t$ (163) $=-5.82 ; p<.01)$. W badanej grupie większe nasilenie miała pozytywna postawa wobec seniorów (zob. wykres 1).

\section{Wiedza studentów o starości}

Wyniki w Kwestionariuszu wiedzy o starzeniu się Palmore'a wahały się od 4 do $20(M=12.97$; $S D=2.69$ ). Rozkład wyników był zbliżony do normalnego, co przedstawiono na wykresie 2. 
Wybrane uwarunkowania postaw osób u progu dorostości wobec starości i seniorów

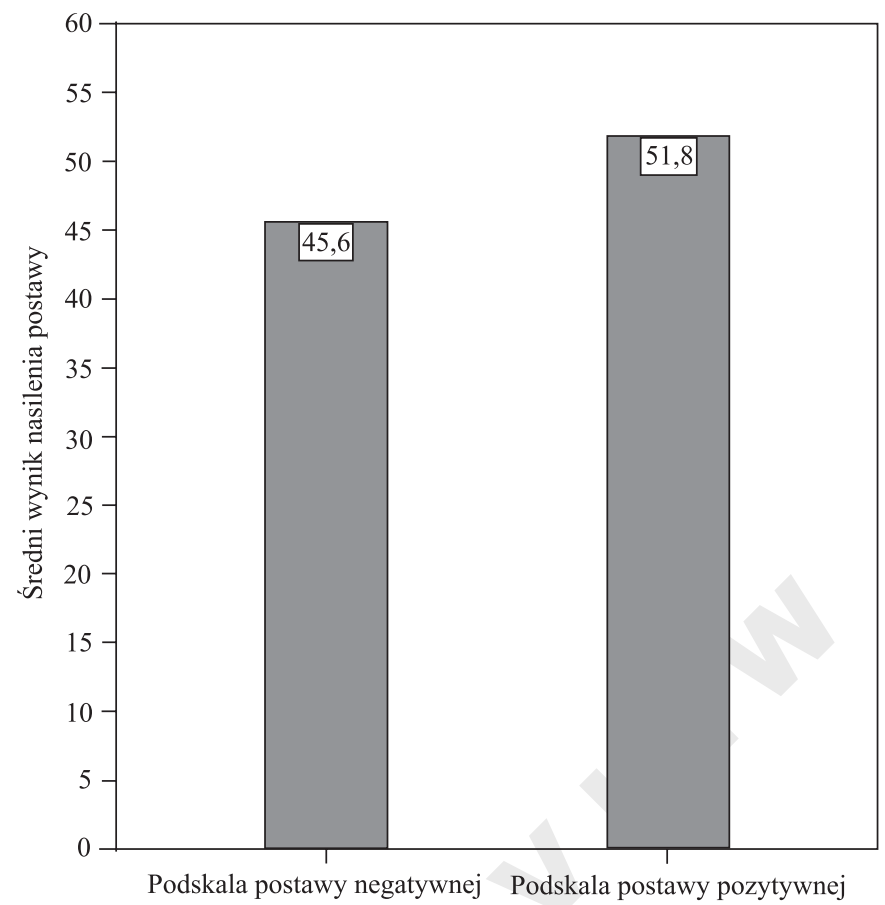

Wykres 1. Średnie wyniki nasilenia postaw wobec osób starszych

Źródło: opracowanie własne.

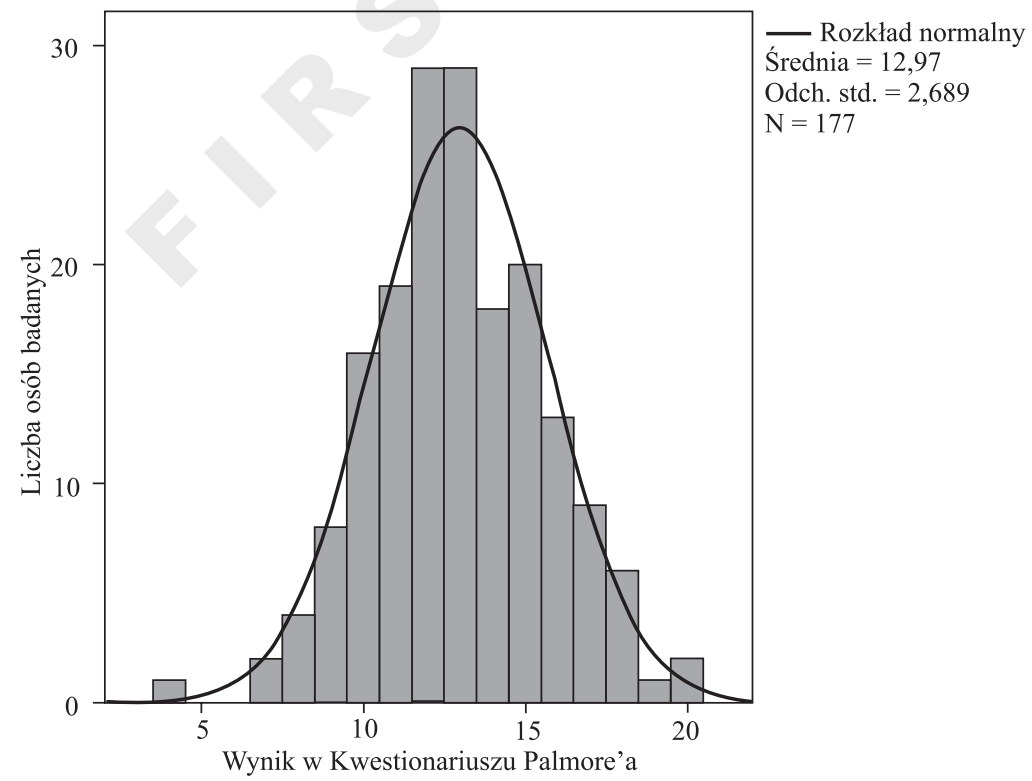

Wykres 2. Rozkład wyników w Kwestionariuszu Palmore'a

Źródło: opracowanie własne. 
Zastosowane statystyki wykazały, że płeć nie była zmienną różnicującą wyniki uzyskane przez badanych, dlatego nie zostały tutaj zamieszczone oddzielne analizy dla kobiet i mężczyzn. Poniżej zaprezentowane zostaną wyniki odpowiednie dla sformułowanych hipotez.

\section{Wiedza o starości i częstość kontaktu z seniorami osób wkraczających w dorosłość a ich postawy wobec seniorów}

Hipoteza 1. Istnieje pozytywny związek między wiedzą na temat starości i starzenia się osób wkraczających w dorosłość a ich postawą wobec osób w wieku senioralnym.

Analizie poddano dane zebrane od 170 osób. Ze względu na niekompletne dane (niewypełniony jeden z kwestionariuszy), arkusze dziesięciu osób nie zostały uwzględnione w obliczeniach. Aby zweryfikować hipotezę 1, przeprowadzono analizę korelacji r Pearsona między wynikami w Kwestionariuszu wiedzy o starzeniu się Palmore'a wskazującymi na poziom wiedzy badanych o starości i starzeniu się a ich wynikami w podskalach postaw pozytywnej i negatywnej mierzonych z użyciem Kwestionariusza Kogana. Wystapiły istotne statystycznie korelacje między poziomem wiedzy o starości a postawami wobec starości. Poziom wiedzy pozostaje $\mathrm{w}$ dodatnim związku z postawą pozytywną $(r=.38)$, a ujemnym z postawą negatywną $(r=-.35)$ wobec starości, co oznacza, że im większą wiedzę o okresie senioralnym mają studenci, tym bardziej pozytywne i mniej negatywne postawy ujawniają wobec seniorów.

Hipoteza 2. Częstość kontaktu osób wkraczających w dorosłość z seniorami związana jest z jakością ich postawy wobec seniorów. Im częściej młodzi ludzie kontaktują się z seniorami, tym bardziej nasilona jest ich pozytywna postawa, a mniej nasilona negatywna wobec osób starszych.

Analizie poddano dane pochodzace od 164 osób. Szesnaście osób zostało wykluczonych ze względu na brak odpowiedzi na wszystkie pytania dotyczące częstości kontaktu z osobami starszymi lub niewypełnienie Kwestionariusza Kogana. Częstość kontaktu zdefiniowano jako sumę odpowiedzi na trzy pytania zawarte w An- kiecie Kontaktu z Osobami Starszymi („,1. Czy ma Pan/Pani kontakt z osobami starszymi?"; „2. Czy miał/miała Pan/Pani kontakt z osobami starszymi w przyszłości?”; „3. Jak często kontaktuje lub kontaktował/kontaktowała się Pan/ Pani z osobami starszymi?"). Większa liczba punktów oznaczała częstszy kontakt z seniorami. Przeprowadzono analizę korelacji r Pearsona między wartościami zmiennej częstości kontaktu a wynikami w podskalach postawy pozytywnej i postawy negatywnej Kwestionariusza Kogana. Otrzymane wyniki przedstawia tabela 1.

Tabela 1. Korelacja r Pearsona zmiennych: Częstość kontaktu z seniorami i postawy wobec osób starszych

\begin{tabular}{|c|c|c|}
\hline $\begin{array}{c}\text { Podskala postawy } \\
\text { w Kwestionariuszu } \\
\text { Kogana }\end{array}$ & $\boldsymbol{N}$ & $\begin{array}{c}\text { Częstośćc } \\
\text { kontaktu } \\
\text { z osobami } \\
\text { starszymi }\end{array}$ \\
\hline Postawa pozytywna & 164 & .11 \\
\hline Postawa negatywna & 164 & $-.26^{*}$ \\
\hline
\end{tabular}

$*$ korelacja istotna statystycznie na poziomie $p<.01$

Źródło: opracowanie własne.

Związek częstości kontaktu z postawą pozytywną wobec osób starszych nie osiagnął istotności statystycznej, natomiast wystąpiła istotna statystycznie korelacja $(r=-0.26)$ między częstością kontaktu z osobami starszymi a nasileniem postawy negatywnej. Częstszy kontakt z osobami starszymi pozostaje w ujemnym związku z nasileniem postawy negatywnej, co oznacza, że wraz ze wzrostem częstości kontaktu z osobami starszymi osłabia się prezentowana przez studentów postawa negatywna wobec nich.

\section{Jakość kontaktu studentów z seniorami a ich postawy wobec osób starszych}

Hipoteza 3. Istnieje związek między jakością kontaktów osób wkraczających w dorosłość z seniorami a ich postawami wobec seniorów. Oczekiwano, że badani relacjonujący pozytywny kontakt $\mathrm{z}$ seniorami w porównaniu $\mathrm{z}$ ró- 
wieśnikami o gorszym kontakcie ujawniają bardziej pozytywną postawę wobec osób starszych, a mniej nasiloną postawę negatywną.

Do analizy wykorzystano dane pochodzące od 164 osób. Miarą jakości kontaktu badanych z osobami starszymi była subiektywna ocena kontaktu z seniorami uzyskana na podstawie odpowiedzi udzielonej przez studentów na pytanie „Jak oceniasz kontakt z seniorami?” (poprzez zaznaczenie jednej z trzech możliwości: negatywnie, nie mam zdania, pozytywnie).
Nikt z badanych nie określił jakości kontaktu „negatywnie”, a zdecydowana większość udzieliła odpowiedzi „pozytywnie” (79,4\%), pozostali wskazali opcję: „nie mam zdania”. W celu sprawdzenia, jak kształtuje się nasilenie postawy pozytywnej i negatywnej wobec seniorów, w grupach studentów oceniających własne kontakty z seniorami jako: ,pozytywne” i ,nie mam zdania” wykonano test t-Studenta dla prób niezależnych. Wyniki przedstawiono w tabeli 2 oraz na wykresie 3 .

Tabela 2. Nasilenie postawy pozytywnej i negatywnej wobec seniorów w grupach studentów oceniających własne kontakty z seniorami jako: ,pozytywne” i „,nie mam zdania”

\begin{tabular}{|c|c|c|c|c|c|c|}
\hline $\begin{array}{c}\text { Podskala postawy } \\
\text { w Kwestionariuszu } \\
\text { Kogana }\end{array}$ & $\begin{array}{l}\text { Subiektywna ocena } \\
\text { jakości kontaktu } \\
\text { z osobami starszymi }\end{array}$ & $N$ & $\begin{array}{c}\text { Średni wynik } \\
\text { nasilenia } \\
\text { postawy }\end{array}$ & $S D$ & Test $t$ & $\begin{array}{l}\text { Wielkość } \\
\text { efektu d } \\
\text { Cohena }\end{array}$ \\
\hline \multirow{2}{*}{$\begin{array}{l}\text { Podskala postawy } \\
\text { pozytywnej }\end{array}$} & Pozytywna & 132 & 52.85 & 6.57 & \multirow{2}{*}{$-4.22 *$} & \multirow{2}{*}{.84} \\
\hline & Nie mam zdania & 32 & 47.41 & 6.41 & & \\
\hline \multirow{2}{*}{$\begin{array}{l}\text { Podskala postawy } \\
\text { negatywnej }\end{array}$} & Pozytywna & 132 & 44.31 & 7.94 & \multirow{2}{*}{$4.13 *$} & \multirow{2}{*}{.81} \\
\hline & Nie mam zdania & 32 & 50.81 & 8.20 & & \\
\hline
\end{tabular}

* różnica istotna statystycznie na poziomie $p<.01$

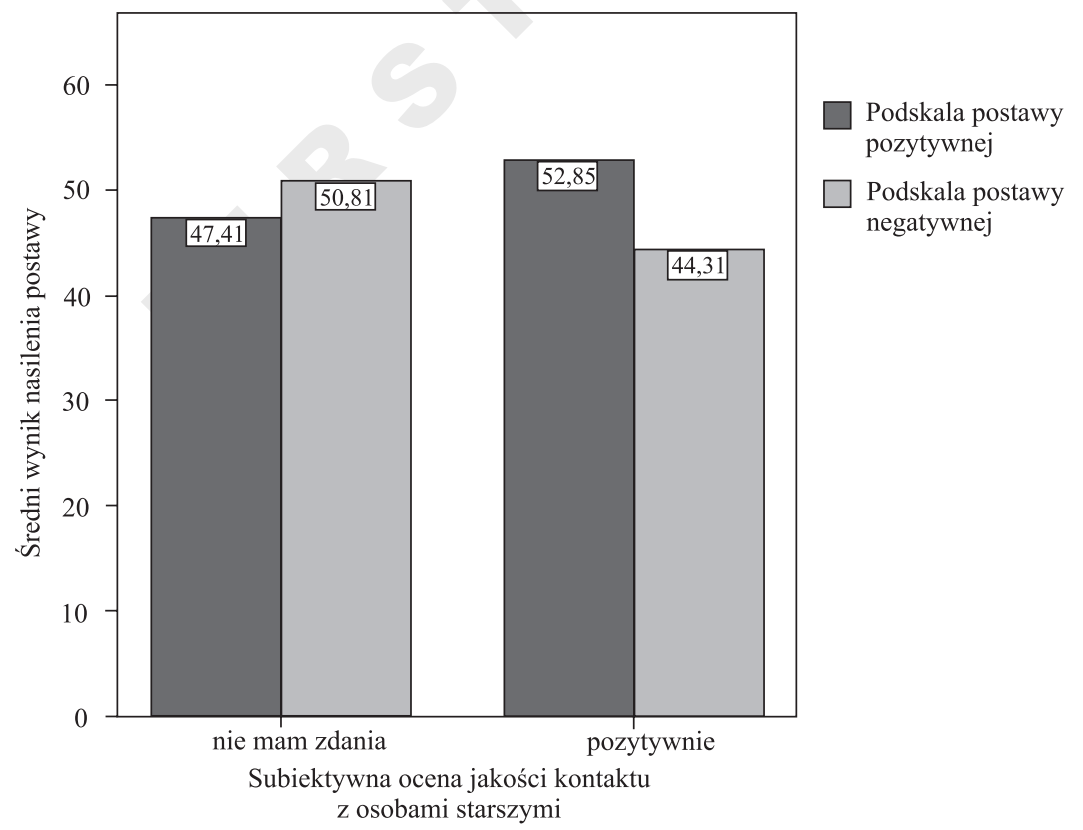

Wykres 3. Różnice wyników w Kwestionariuszu postaw wobec osób starszych Kogana i subiektywnej oceny jakości kontaktu z osobami starszymi

Źródło: opracowanie własne. 
Wystąpiły istotne statystycznie różnice między nasileniem zarówno postawy pozytywnej, jak i negatywnej w grupach studentów, którzy odmiennie oceniali jakość kontaktu z seniorami. Studenci pozytywnie oceniający własne relacje z seniorami w porównaniu z tymi, którzy nie mieli zdania w tej kwestii, przejawiali bardziej nasiloną pozytywną postawę wobec seniorów ( $M p 1$ $=52.85, S D 1=6.57, M p 2=47.41, S D 2=6.41)$ oraz mniej nasiloną negatywną postawę $(M n 1=$ 44.31, SD1 = 7.94, Mn2 = 50.81, SD2 = 8.20).

\section{Predyktory postaw (pozytywnej/ negatywnej) osób wkraczających w dorosłość wobec seniorów}

Hipoteza 4. Wiedza badanych studentów na temat seniorów i procesu starzenia się stanowi najważniejszy predyktor spośród rozważanych uwarunkowań ich postawy wobec osób starszych.
Aby określić udział kontrolowanych zmiennych w nasileniu poszczególnych postaw studentów wobec osób starszych, przeprowadzono analizy regresji krokowej, w których zmiennymi objaśniającymi były: poziom wiedzy studentów o starości, subiektywna ocena jakości kontaktów z osobami starszymi, częstość kontaktów z osobami starszymi oraz płeć, a zmiennymi objaśnianymi kolejno: nasilenie postawy pozytywnej i nasilenie postawy negatywnej wobec seniorów. Właściwości powstałych modeli przedstawia tabela 3 .

Predyktorami zmiennej objaśnianej nasilenie postawy pozytywnej wobec seniorów okazały się zmienne: poziom wiedzy o starości, jakość oceny kontaktów oraz płeć. Przy czym największe znaczenie miał poziom wiedzy o seniorach. Wyższy poziom wiedzy o starości oraz pozytywna ocena jakości kontaktów z osobami starszymi deklarowana przez studentki pozwalają prognozować większe nasilenie ich postawy

Tabela 3. Modele analizy regresji krokowej dla zmiennych objaśniających: poziom wiedzy o starości, subiektywna ocena jakości kontaktów z osobami starszymi, częstość kontaktów z osobami starszymi, i zmiennych objaśnianych: postawa pozytywna i postawa negatywna wobec osób starszych

\begin{tabular}{|c|c|c|c|c|c|c|}
\hline $\begin{array}{c}\text { Zmienna } \\
\text { objaśniana }\end{array}$ & Model & Predyktory & $N$ & Współczynnik B & R-kwadrat & Istotność \\
\hline \multirow{6}{*}{$\begin{array}{l}\text { Podskala } \\
\text { postawy pozy- } \\
\text { tywnej }\end{array}$} & 1 & Wiedza & 164 & 1.05 & .16 & $<.01$ \\
\hline & \multirow{2}{*}{2} & Wiedza & \multirow{2}{*}{164} & 1.0 & \multirow{2}{*}{.24} & \multirow{2}{*}{$<.01$} \\
\hline & & Jakość & & 4.95 & & \\
\hline & \multirow{3}{*}{3} & Wiedza & \multirow{3}{*}{164} & 1.0 & \multirow{3}{*}{.27} & \multirow{3}{*}{$<.01$} \\
\hline & & Jakość & & 5.18 & & \\
\hline & & Płeć & & 2.15 & & \\
\hline \multirow{10}{*}{$\begin{array}{l}\text { Podskala po- } \\
\text { stawy nega- } \\
\text { tywnej }\end{array}$} & 1 & Wiedza & 164 & -1.15 & .13 & $<.01$ \\
\hline & \multirow{2}{*}{2} & Wiedza & \multirow{2}{*}{164} & -1.08 & \multirow{2}{*}{.21} & \multirow{2}{*}{$<.01$} \\
\hline & & Jakość & & -5.96 & & \\
\hline & \multirow{3}{*}{3} & Wiedza & \multirow{3}{*}{164} & -1.11 & \multirow{3}{*}{.24} & \multirow{3}{*}{$<.01$} \\
\hline & & Jakość & & -4.5 & & \\
\hline & & Częstość & & -.73 & & \\
\hline & \multirow{4}{*}{4} & Wiedza & \multirow{4}{*}{164} & -1.1 & \multirow{4}{*}{.26} & \multirow{4}{*}{$<.01$} \\
\hline & & Jakość & & -4.95 & & \\
\hline & & Częstość & & -.64 & & \\
\hline & & Płeć & & -2.45 & & \\
\hline
\end{tabular}

Źródło: opracowanie własne. 
pozytywnej. W analizie regresji dla nasilenia postawy negatywnej, jako zmiennej objaśnianej, najsilniejszym predyktorem także okazał się poziom wiedzy o starości. Kolejnymi predyktorami włączonymi do modelu były: ocena jakości kontaktów z osobami starszymi, częstość kontaktów z osobami starszymi oraz płeć. Niższy poziom wiedzy oraz brak pozytywnej oceny jakości kontaktów z osobami starszymi pozwalają prognozować większe nasilenie postawy negatywnej. Częstszy kontakt pozwala natomiast prognozować spadek nasilenia postawy negatywnej wobec osób starszych.

\section{DYSKUSJA}

Przedstawione badania własne miały na celu poznanie stanu wiedzy, doświadczeń i postaw wobec seniorów osób wkraczających w dorosłość, a także sprawdzenie zależności między tymi zmiennymi. Polscy studenci reprezentuja przeciętny poziom wiedzy na temat starzenia się i starości, podobny do studentów innych narodowości (por. Lee, 2009; Lucacel, Baban, 2014; Pennington i in., 2001; Unwin, Unwin, Olsen, Wilson, 2008). Średni wynik podskali postawy pozytywnej w Kwestionariuszu postaw wobec osób starszych Kogana okazał się istotnie wyższy niż podskali postawy negatywnej, choć różnica nie była duża. Otrzymane rezultaty świadczą o zróżnicowaniu podejścia współczesnych studentów do seniorów, aczkolwiek bardziej nasilona okazała się postawa pozytywna. Na ambiwalencję postaw wobec osób starszych wśród młodych dorosłych wskazują także badania mierzące postawy utajone (Zając-Lamparska, 2008b).

Wyniki przeprowadzonych analiz korelacji i regresji są zgodne z postawionymi hipotezami i wskazują na znaczenie wyróżnionych w badaniach uwarunkowań postaw badanych studentów wobec seniorów. Szerszemu zakresowi wiedzy towarzyszy bardziej pozytywna postawa oraz mniejsze nasilenie postawy negatywnej. $\mathrm{Na}$ taki związek wskazują też inne badania grupy osób wkraczających w dorosłość (Lee, 2009; Lucacel, Baban, 2014; Snyder, 2005) oraz studentów medycyny i kierunków okołomedycz- nych (Fonseca, Goncalves, Martin, 2009; Hobbs, Dean, Higgs, Adamson, 2006; Milutinovic, Simin, Kacavendic, Turkulov, 2015).

Pomimo wyraźnych korzystnych zmian, które zaszły w ciągu lat w kondycji, aktywności, a także w jakości życia współczesnych seniorów, w społeczeństwie nadal obecny jest negatywny ich obraz jako jednolitej grupy osób schorowanych i wymagających opieki. Wizerunek taki podtrzymywany jest, a niekiedy i wzmacniany, przez działanie mediów prezentujących osoby starsze przede wszystkim w negatywnym świetle. Są one głównie bohaterami reklam leków i suplementów diety. Z kolei w filmach i serialach osoby starsze często stanowią obiekt żartów lub źródło problemów z powodu niedowidzenia lub niedosłyszenia albo trudności w samodzielnym przemieszczaniu się. Jednocześnie media propagują kult młodości oraz wysportowanego i zdrowego ciała, w wyniku czego pośrednio wzmacniany jest negatywny wizerunek osób starszych, daleki od współczesnych standardów piękna i odbiegający od pożądanych wzorców. Tymczasem młodzi ludzie wkraczający w dorosłość, kształtując swoją tożsamość i światopogląd oraz rozwijając nowe relacje społeczne z osobami reprezentującymi też inne pokolenia, często czerpią informacje o świecie z mediów. Zubożenie lub nawet wykluczenie osobistego kontaktu wnuków z dziadkami wynikające ze stylu życia współczesnych jednopokoleniowych rodzin może również ograniczać możliwości młodych ludzi do naturalnego zdobywania wiedzy o starości. Wówczas ich nastawienie do seniorów w dużym stopniu może wynikać z medialnych reprezentacji ludzi starszych, często niezgodnych z rzeczywistym ich wizerunkiem. Niski poziom rzetelnej wiedzy sprzyja bowiem posługiwaniu się schematycznym obrazem przypisanym tej grupie i wyzwala wobec niej negatywną postawę, która może powstrzymywać młodych ludzi przed osobistymi kontaktami z osobami starszymi, zwrotnie utrwalając negatywne nastawienie wobec nich. Ochronę przed takim stereotypizującym spojrzeniem na seniorów może stanowić rzetelna wiedza o nich i procesie starzenia się, która pozwala dostrzec różne oblicza starości: mądrość życiowa, podejmowanie wysiłków rozwojo- 
wych, ale i problemy wynikające z obniżenia sprawności fizycznej oraz chorób doświadczanych częściej niż we wcześniejszym okresie życia. Odkrywana przez młodych wartość tego okresu rozwojowego może motywować ich do częstych kontaktów z seniorami, czerpania z ich doświadczenia, a także poszerzania wiedzy o ich życiu i w konsekwencji kształtowania wobec nich pozytywnej postawy (o czym świadczy pozytywna korelacja między poziomem wiedzy a postawą wobec seniorów).

$\mathrm{W}$ prezentowanych badaniach własnych częstość kontaktu z osobami starszymi okazała się związana jedynie z ujawnianą wobec nich negatywną postawą studentów. Częstszy kontakt sprzyja osłabieniu negatywnej postawy wobec osób starszych. Jest to wynik odmienny od rezultatów dotychczasowych badań (Bousfield, Hutchison, 2010; Schwartz, Simmons, 2001), gdzie zależność ta była nieistotna. Zarówno w badaniach Schwartz i Simmons (2001), jak i w badaniach Bousfield i Hutchisona (2010) częstość kontaktu mierzona była jednym pytaniem z odpowiednio siedmio- i pięciostopniową skalą (od „nigdy” do ,codziennie”), podczas gdy w niniejszej pracy częstość kontaktu mierzono trzema pytaniami z pięciostopniową skalą. Istotność związku częstości kontaktu z postawami może być również tłumaczona rozdzieleniem w analizie podskali postawy pozytywnej i podskali postawy negatywnej. Możliwe, że częstszy kontakt sprzyja osłabieniu postawy negatywnej, dzięki możliwości zdobycia w ten sposób rzetelnej wiedzy na temat osób starszych i weryfikację informacji z rzeczywistym obrazem starości (Hale, 1998).

Związek subiektywnej oceny jakości kontaktu studentów z osobami starszymi był silny zarówno dla postawy pozytywnej, jak i negatywnej. Choć wśród badanych nie pojawiła się osoba, która oceniłaby jakość kontaktu „negatywnie”, to ci, którzy „nie mieli zdania” w porównaniu z pozytywnie oceniającymi kontakt z seniorami, odznaczali się większym nasileniem postawy negatywnej, a mniejszym postawy pozytywnej. Brak deklaracji ,negatywnej" oceny kontaktu z osobami starszymi ze strony badanych może wynikać z faktu, iż mają oni świadomość tego, jaka postawa jest pożądana społecznie, oraz dążą do zaprezentowania korzystnego wizerunku własnej osoby. Dlatego opinia „nie mam zdania” może być tutaj interpretowana jako łagodne określenie braku satysfakcji z obcowania z osobami starszymi. Ocena tego kontaktu formułowana jest na podstawie indywidualnych doświadczeń z konkretnymi seniorami. Zgodnie z mechanizmem generalizacji, ocena może być rozszerzana na całą grupę osób w wieku senioralnym, a w konsekwencji wyznaczać postawę wobec nich. W prezentowanych badaniach zależność ta wystąpiła zarówno u osób, które pozytywnie oceniały własne kontakty z seniorami, jak i u tych, którzy nie potrafili takiej oceny sformułować („nie mam zdania”). Ci drudzy w zestawieniu z zadowolonymi z obcowania z seniorami ujawnili bardziej negatywną postawę. Podobne zależności między jakością kontaktu z osobami starszymi a postawami wobec nich zaobserwowano też w badaniach Schwartz i Simmonsa (2001), a także Bousfield i Hutchisona (2010).

Poziom wiedzy o starości pozwala na przewidywanie nasilenia postawy pozytywnej i negatywnej wobec osób starszych z odpowiednio szesnasto- i trzynastoprocentowym prawdopodobieństwem i jest najsilniejszym predyktorem postaw w analizowanych modelach. Natężenie postawy pozytywnej prognozują także subiektywna ocena jakości kontaktu z osobami starszymi oraz płeć. Częstość jest istotnym predyktorem jedynie dla nasilenia postawy negatywnej. Uzyskane wyniki analizy regresji przemawiają za obecnością innych czynników wpływających na postawy wobec seniorów, które nie zostały uwzględnione w prezentowanych modelach, a które powinny być włączone w kolejnych eksploracjach. Jednym z nich jest obecność osób starszych w rodzinie, ale także posiadane wzorce kontaktu z osobami starszymi wyniesione $\mathrm{z}$ domu rodzinnego. Postawy młodych ludzi wobec osób starszych uwarunkowane mogą być też doświadczeniami tych pierwszych związanymi ze sprawowaniem opieki nad seniorem. Pomoc i opieka nad starszymi ułatwia zrozumienie starości i jej konsekwencji oraz uwrażliwia na potrzeby osób w podeszłym wieku. Kolejnym czynnikiem, którego obecność 
może być silnie związana z postawami osób wkraczających w dorosłość wobec seniorów jest obecność w rodzinie osoby starszej cierpiącej na chorobę neurodegeneracyjną, jak na przykład otępienie lub naturalna demencja. Postępujące zmiany w psychice i zachowaniu osoby chorej znacząco obciążają rodzinę. Zaangażowanie w opiekę nad chorym, zrozumienie choroby i jej konsekwencji oraz sposoby radzenia sobie ze stresem mogą przekładać się na postawy wobec starości i osób starszych.

Przedstawione wyniki badań własnych wzmacniają prezentowaną w literaturze zależność między wiedzą młodych ludzi o seniorach a ich postawami wobec osób starszych, a także dostarczają nowych informacji na temat zależności między częstością kontaktów młodych Polaków z osobami starszymi a nasileniem ich negatywnej postawy wobec nich, wskazując, że częstsze kontakty osłabiają negatywną postawę. Subiektywna ocena jakości kontaktu również ma związek z postawami. Zaproponowana procedura badawcza pozwala na stworzenie schematu zależności, które zachodzą między postawą pozytywną i postawą negatywną a poziomem wiedzy na temat starzenia się i starości oraz częstością i jakością kontaktów z osobami starszymi. Przedstawia je rycina 1.

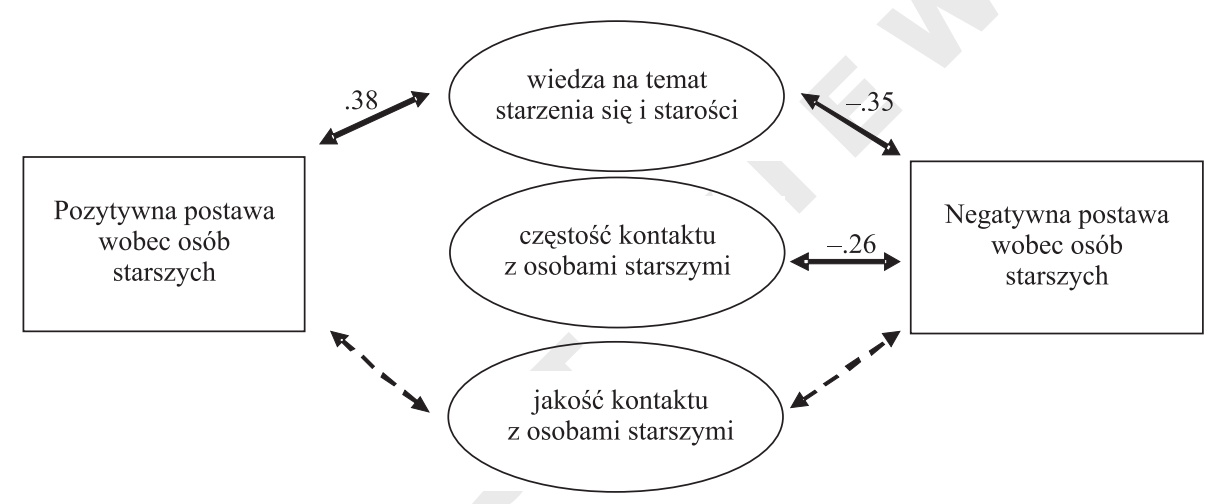

Rycina 1. Czynniki związane z postawą pozytywną i postawą negatywną osób wkraczających w dorosłość wobec osób starszych

Źródło: opracowanie własne.

\section{REFLEKSJE KOŃCOWE}

Wkraczanie w dorosłość to czas obniżonej stabilności stylu życia młodych ludzi, a jednocześnie intensywnie przebiegającego procesu kształtowania ich tożsamości, dlatego ważne jest wspieranie w tym okresie życia formowania się pozytywnej postawy wobec osób starszych i minimalizowanie nasilania postawy negatywnej wobec nich. Jest to możliwe poprzez dostarczanie młodym ludziom rzetelnej wiedzy na temat starości i starzenia się oraz stwarzanie przyjaznej atmosfery kontaktów międzygeneracyjnych, co w konsekwencji może owocować ich większą częstością.
Dla umocnienia otrzymanych wyników należy w przyszłych badaniach wykorzystać narzędzia (zarówno do badania wiedzy o seniorach, jak i postaw wobec nich) o lepszych właściwościach psychometrycznych. Modyfikacji wymaga też sposób badania jakości kontaktu z osobami starszymi. Brak znaczenia jakości kontaktów studentów z seniorami, przy uwzględnieniu innych uwarunkowań (częstość kontaktów, wiedza o starości oraz płeć), dla jakości postawy wobec osób starszych może wynikać właśnie ze sposobu oceny kontaktów na podstawie odpowiedzi na pojedyncze pytanie. Interesującą kontynuacją byłyby także badania nad związkiem przyczynowo-skutkowym mię- 
dzy oceną jakości kontaktu z osobami starszymi a postawami wobec nich. Wskazana byłaby również dalsza eksploracja czynników, które mogą być związane z postawami wobec osób starszych, takich jak na przykład: obecność osób starszych cierpiących na choroby neurodegeneracyjne w rodzinie oraz pomoc i opieka nad nimi. Pozwoliłoby to na opracowanie bardziej wyczerpującego schematu interakcji i poznanie ewentualnych moderacji między zmiennymi.

Przedstawione badania własne dotyczyły analizy postaw i ich korelatów wśród osób wkraczających w dorosłość, natomiast dla stworzenia ogólnego modelu zależności konieczne jest przebadanie różnych grup wiekowych.

\section{BIBLIOGRAFIA}

Arnett J.J. (2004), Emerging Adulthood: The Winding Road from the Late Teens through the Twenties. New York: Oxford University Press.

Arnett J.J. (2006), Emerging adulthood: Understanding the new way of coming of age. W: J.J. Arnett, J.L. Tanner (eds.), Emerging Adults in America: Coming of Age in the 21st Century, 3-19. Washington: American Psychological Association.

Bousfield C., Hutchison P. (2010), Contact, anxiety, and young people's attitudes and behavioral intentions towards the elderly. Educational Gerontology, 36, 6, 451-466.

Butler R.N. (1980), Ageism: A foreword. Journal of Social Issues, 36, 2, 8-11.

Denmark F.L. (2002). Myths of aging: Eye on Psi Chi, The National Honor Society in Psychology. Distinguished Lectures/Special Topics, 7(1), 14-21.

Department of Economic and Social Affairs, Population Division (2015), World Population Ageing 2015. New York: United Nations.

Fonseca A., Goncalves D., Martin I. (2009), Changing attitudes towards ageing and the aged amongst psychology students. European Journal of Education, 44, 3, 455-466.

Gurba E. (2011), Wczesna dorosłość. W: J. Trempała (red.), Psychologia rozwoju człowieka Podręcznik akademicki, 287-311. Warszawa: Wydawnictwo PWN.

Hale N.M. (1998). Effects of age and interpersonal contact on stereotyping of the elderly. Current Psychology, 17, 1, 28-47.

Hobbs C., Dean C.M., Higgs J., Adamson B. (2006), Physiotherapy students' attitudes towards and knowledge of older people. Australian Journal of Physiotherapy, 52, 115-119.

Kalfoss M., Halvorsrud L. (2009), Important issues to quality of life among Norwegian older adults: An exploratory study. The Open Nursing Journal, 3, 44-55.

Kogan N. (1961), Attitudes toward old people: The development of a scale and examination of correlates. Journal of Abnormal and Social Psychology, 62, 1, 44-54.

Levy B.R., Slade M.D., Kunkel S.R., Kasl S.V. (2002), Longevity increased by positive self-perceptions of aging. Journal of Personality and Social Psychology, 83, 261-270.

Lucacel R., Baban A. (2014), Young people perspective regarding aging. Cognition, Brain, An Interdisciplinary Journal, 18, 2, 151-161.

Milutinovic D., Simin D., Kacavendic J., Turkulov V. (2015), Knowledge and attitudes of health care science students toward older people. Medicinski Pregled, 68, 11-12, 51-55.

Miłkowska G. (2014), Analiza postaw społecznych wobec ludzi starszych na podstawie opinii studentów. Rocznik Polsko-Ukraiński, 25, 177-192.

Molzhan A., Skevington S.M., Kalfoss M., Makaroff K.S. (2010), The importance of facets of quality of life to older adults: An international investigation. Quality of Life Research. An international Journal of Quality of Life Aspects of Treatment, Care and Rehabilitation - Official Journal of the International Society of Quality of Life Research, 19, 293-298.

National Institute on Aging and World Health Organization (2011), Global Health and Aging Publication 117737. Bethesda, MD: National Institute on Aging. 
Ostril G.V., Ottenbacher J.K., Markides K.S. (2004), Onset of frailty in older adults and the protective role of positive affects. Psychology and Aging, 19, 402-408.

Palmore E. (1977), Facts on aging: A short quiz 1. Gerontologist, 17, 4, 315-320.

Pennington H.R., Pachana N.A., Coyle S.L. (2001), Use of facts on aging quiz in New Zealand: Validation of questions, performance of a student sample, and effects of a don't know option. Educational Gerontology, 27, 409-416.

Romeis J.C., Sussman M.B. (1982), Cross cultural differences on the facts on ageing quiz: Additional comments on age bias. Cambridge University Press 1982, 2, 3, 257-370.

Schwartz L.K., Simmons J.P. (2001), Contact quality and attitudes toward the elderly. Educational Gerontology, 27, 2, 127-137.

Snyder J.R. (2006), The influence of instruction on college students' attitudes toward older adults. Gerontology \& Geriatrics Educations, 26, 2, 69-79.

Social Europe (2011), Demography Report 2010: Older, More Numerous and Diverse Europeans, Luxembourg: Publications Office of the European Union.

Szatur-Jaworska B. (2015), Dyskryminacja ludzi starszych ze względu na wiek w obszarze pomocy społecznej. W: B. Tokarz (red.), Co wiemy o dyskryminacji ze względu na wiek? Głos ekspertów, doświadczenia osób starszych. Warszawa: Akademia Rozwoju Filantropii w Polsce.

TNS Opinion \& Social (2009), Discrimination in the EU in 2009. Special Eurobarometer 317, 71, 2, Brussels: European Commission.

Trempała J., Zając-Lamparska L. (2007), Postawy wobec osób starszych: różnice międzypokoleniowe. Przegląd Psychologiczny, 50, 4, 447-462.

Unwin B.K., Unwin C.G., Olsen C., Wilson C. (2008), A new look at an old quiz: Palmore's facts on Aging Quiz turns 30. Journal of the American Geriatrics Society, 56, 11, 2162-2164.

Waszkiewicz L., Einhorn J., Połtyn-Zaradna K., Gaweł-Dąbrowska D., Grabowska B., Zatońska K. (2012), Ocena jakości życia Polaków w wieku podeszłym. W: M. Mossakowska, A. Więcek, P. Błędowski (red.), Aspekty medyczne, psychologiczne, socjologiczne i ekonomiczne starzenia się ludzi w Polsce, 549-560. Poznań: Termedia Wydawnictwo Medyczne.

Wojciszke B. (2011), Psychologia społeczna. Warszawa: Wydawnictwo Naukowe Scholar.

Zając-Lamparska L. (2008a), Współczesny obraz człowieka starszego wśród młodych dorosłych. Polskie Forum Psychologiczne, 13, 2, 124-140.

Zając-Lamparska L. (2008b), Postawy utajone wobec osób starszych, przejawiane w trzech grupach wiekowych: wczesnej, średniej i późnej dorosłości. Psychologia Rozwojowa, 13, 3, 91-102. 